\title{
Profiling Expelled Students
}

\author{
K.J. Kirkwood \\ W. Richardson \\ Nipissing University
}

\begin{abstract}
The purpose of this study was to determine what, if any, demographic trends exist respecting students expelled for violent behavior. The data collected from 104 confidential student files were used to profile each of the following:

A. The violent student,

$B$. The nature of school violence, and

C. How schools are dealing with violent students.
\end{abstract}

The student expelled for violent behavior is typically male, between the ages of 15 and 18, has a history of previous suspension and has average to below-average academic skills. The incidents of violence occur in common areas of the school, are rarely directed toward staff and teachers, involve a weapon, and are classified as aggravated assaults. Schools are directly involving the police, expelling students for extended periods of time

Dr. Kristian John Kirkwood is currently the Chair of the Graduate Department in Education at Nipissing University in North Bay, Ontario. His current research interests include research methodologies, teacher absenteeism, and students who are at-risk within the education system.

Dr. Warnie Richardson is Associate Professor of Special Education / Educational Psychology at Nipissing University in North Bay, Ontario. His research interests include the education of at-risk and/or marginalized students. He has worked for a number as years, as an educator, within the juvenile justice system. 
and have, in a small number of incidents, readmitted expelled students. Conditions of readmission include reference letters, psychological assessment and a review of academic performance.

\section{Résumé}

Cet article décrit les résultats d'une étude démographique d'élèves renvoyés de l'école à cause de leur comportement violent. Les données recueillies en examinant 104 dossiers confidentiels ont servi à préciser trois aspects de la question à l'étude: l'élève violent, la nature de la violence à l'école et les moyens utilisés par les écoles pour traiter de ces élèves violents. Le profil typique de l'élève renvoyé de l'école est un mâle âgé de 15 à 18 ans, qui a été suspendu dans le passé et dont les résultats scolaires sont de niveau moyen ou en-dessous de la moyenne. Les incidents de violence ont lieu dans les espaces publics de l'école et portent rarement sur le personnel enseignant ou administratif. Puisqu'ils comportent l'utilisation d'une arme, ils sont caractérisés d'agression et de tentative de voie de fait.

Les écoles font appel directement à la police et renvoient les élèves pendant une longue durée. Dans certains cas, plus rares, les écoles ont ré-admis les élèves renvoyés en exigeant des lettres de référence, une évaluation psychologique et un nouvel examen de résultats scolaires.

\section{Introduction and Background}

The recent killings by students in high schools across North America have increased the intensity of interest in the issue of school violence. Whatever the sources may be, whether cultural or domestic or personal, there have been instances of students shooting other students and staff for over 20 years. For principals, however, dealing with school violence is not an isolated, intense experience; it is a constant concern.

Historically, there have always been instances within the schooling environment where antagonism between students escalates into physical confrontations (Roher, 1993). As well, it has long been known that a percentage of students will be openly and clearly hostile to the controls and evaluations placed on them by the school, with much of this hostility being eventually expressed in acts of classroom 
defiance or vandalism (Horowitz and Tobaly, 2003; Chan, 1996).

Traditionally, most incidents of fighting, unruliness, and vandalism were dealt with within the classroom or by imposing brief periods of inschool or out-of-school suspension. However, over recent years, this more discretionary approach to discipline has been supplanted by a far less tolerant one, one which imposes strict new standards on overall deportment (often referred to as zero tolerance), with long-term expulsion serving as the ultimate sanction (Kalinowski, 2003; 2005). For example, in the current climate here in the province of Ontario, a student who brings a weapon to school, threatens a teacher or student with a weapon, or assaults anyone with a weapon, will, after an internal hearing generally conducted by the board itself, be forbidden from attending not only the school in which the specific infraction occurred, but any other school under the board's direct jurisdiction for an indefinite period (Kalinowski, 2005; Ontario Ministry of Education, 2001; Heaviside et al., 1998).

Students have always fought with one another, and a few express hostility through vandalism (Horowitz and Tobaly, 2003). Most fighting and vandalism are dealt with via suspensions, some brief and some for several weeks. In recent years, notions of zero tolerance have led some schools and/or school systems, in ever- increasing numbers, to impose new standards, with expulsions as the ultimate penalty (Kalinowski, 2005).

To study this process we examined data from 28 secondary schools of a large suburban school system. We were interested in expulsions: when and why they were made; what appeals were possible; how frequent were the expulsions. By inference, if one studies expulsions, one should be able to get an impression of the kinds of problems with serious violence that principals face.

\section{Method}

The data were collected from the confidential files of 104 students who were expelled by the school board. The school board is situated in southern Ontario and is one of the largest public boards in Canada. The data collected represented expulsion cases for the past 
10 years up to the Safe School Act of 2002.

The demographic trends found to exist respecting students expelled for violent behavior were presented as frequencies and percentages, and were determined based on the exploration of several heuristically selected variables. Three areas of interest emerged based on the demographic trends revealed by the analysis of the data. For each of the three sections of this study, the research questions are restated and the corresponding answers are given.

\section{Findings}

\section{A. Profiling the Violent Student}

The variables used to profile the violent student were:

- gender,

- age,

- ethnic background,

- previous history of suspensions,

- $\quad$ academic achievement, and

- previous history of criminal conviction.

Gender Differences: The results of the study are conclusive and consistent with similar studies (Anon, 1999). Males are primarily involved in, and expelled for, incidents of school violence (Siegel et al., 2003, p. 169). In $89 \%$ of the cases studied, males were the instigators of the violence. In the Pilot Project for Expelled Students, prepared by F. Mathews of the Central Toronto Youth Services, males represented $80 \%$ of the expelled students referred to the program in the 1991 to 1992 school year and $88 \%$ of the referred students in the 1992 to 1993 school year. These figures are based on expulsions that occurred in Toronto, Southern Ontario and Northern Ontario public secondary schools (Mathews, 1995, p. 13). In a similar study, conducted in Texas, findings indicated that in $77 \%$ of the incidents, the offenders were male (Texas Education Agency, 1995, p. 22).

These results of the study do not confirm claims that female 
school violence is on the increase. Expulsions of students analyzed by gender and year indicate a constant frequency of occurrence over the span of this study.

Age Differences: In $83 \%$ of the cases, the students were between the ages of 15 and 18 . The high percentage of students falling in this age range is not surprising given that secondary schools service students in this age bracket. The data indicate that $49 \%$ of the expelled students were 17 to 18 years of age. These results suggest that students in the 11th and 12th grades are at the highest risk of expulsion for violent behavior. The low percentage of students 20 and over is not surprising since the number of students over 20 in secondary schools is typically small.

Ethnic Differences: The data in the student files that were made available for analysis in this study (with the exception of a few cases) generally did not convey sufficient information to enable us to draw broad conclusions with regard to the relationship between students expelled for violent behavior and ethnic differences. However, analysis of the data for which specific ethnic background was made known to us, indicated that more than one-half of the students expelled for violent behavior were of Jamaican origin. These results, although limited in overall scope, nevertheless are consistent with several other studies that indicate a relationship between violent behavior and ethnic background (Sampson et al., 2005; Hawkins et al., 2000; Paschall et al., 1998; Gibbons and Krohn, 1986, p. 65).

In his study of expelled students, Mathews (1995) found that "youth in the program came from a variety of cultural backgrounds, though 50\% were from families of Caribbean origin" (p. 14). In a similar report on school violence among culturally diverse populations, categories of risk are identified (in decreasing order) as "Black, Hispanic and White, respectively" (Soriano et al., 1994, p. 218).

In contrast, the Update to the National Institute of Justice Survey (1993) found that victimization rates "did not differ significantly across racial and ethnic lines, socio-demographic characteristics, age categories, or grade levels. Only gender seemed to relate to victimization levels, with males significantly more likely to have 
experienced a shooting, stabbing or other weapon related assault" (Sheley et al., 1995, p. 25). Further data are necessary to profile more accurately the differences in ethnic background of students expelled for violent behavior and consequently, the results of this study must be reported with a considerable degree of caution.

Previous History of Suspension: In a few isolated incidents, students expelled for violent behavior did not have a history of previous suspensions. However, in $93 \%$ of the cases students had been previously suspended from a secondary school. Violent students frequently have a history of suspensions, prior convictions and low academic achievement (Siegel et al., 2003, pp. 270-276).

Further, there is now a significant body of research supporting the hypothesis that young criminals, meaning those who have been "officially" processed by the juvenile justice system, are much more likely to have experienced dysfunction within their previous schooling experiences prior to their arrests and incarceration (Richardson, 2003; West, 1984, p. 147; Shannon, 1982; Wolfgang, et al., 1972).

This study did not explore the differences between the percentage of students suspended but not expelled and the percentage of students suspended and subsequently expelled. This level of data collection was beyond the scope of this study.

Academic Achievement: The results of this study are conclusive and consistent with similar studies that consider violent behavior and academic achievement (Estevez et al., 2005; Leblanc et al., 1993). "Low-achieving students are the most likely perpetrators of school violence" (Booth et al., 1993, p. 17). Or, as Gordon West more succinctly puts it, "dozens of independent studies across cultural and linguistic boundaries have repeatedly found school failure to be among the most persistent and strongest correlates of both out-of-school official juvenile delinquency, in-class misbehaviour, and self-reported delinquent behaviour" (1984, p. 147). Polk and Shafer (1972), along with Manning and Baruth, would not disagree (1995, pp. 45-47).

In this study, academic achievement data were available for $68 \%$ of the students. In $67 \%$ of the known cases, students were identified as below-average achievers. Similar studies iterate similar 
findings (Brunner, 1993; Finn, 1988). One disturbing finding in Mathews's Pilot Project for Students Expelled for Violent Behaviour (1995), cited previously, was that $67 \%$ of the sampling were identified as having a specific learning disability. (p. 15).

Researchers attribute many of the systemic causes of violence to the students' inability to "fit" into the school community or society (Richardson, 2005, pp. 33-40; Mathews, 1995, p. 15; Hunter, 1993, p. 53; Walker \& Sylwester, 1991, p. 14). For example, as alluded to above, learning disabilities hinder a student's ability to fit into the school community; a community where the parameters that measure success are well defined (Fink, 1990; Holzman, 1979; Murray, 1976).

Previous History of Criminal Conviction: Data on prior criminal convictions were obtained from the student files supplied by the school board. Actual police records were not used in the creation of the tables on the history of a student's prior convictions. From the available data, in $86 \%$ of the cases students had a history of prior convictions. These results support the results of similar studies that illustrate the relationships that exist between school violence and prior convictions (Callahan and Rivara, 1992). In particular, Mathews's Pilot Project for Students Expelled for Violent Behaviour (1995) found that 50\% of the students enrolled in the program had a history of prior convictions. The results of this study support findings in the literature that indicate that antisocial adolescents are a high-risk group for school violence (Leone et al., 2000; McEvoy \& Welker, 2000; Agnew and Brezina, 1997;

Short and Strodtbeck, 1965).

\section{B. Profiling the Nature of the Violence}

The variables used to profile the nature of the violent behavior were:

- use of weapons,

- location of the incident,

- $\quad$ gang-related incidents,

- $\quad$ nature of the violence, and

- teacher involvement. 
Types of Weapons Used: The data indicate that $91 \%$ of the students expelled possessed a weapon and that in $66 \%$ of the incidents the weapon used was a knife. The types of knives used included exacto knives, paring knives, pocket knives and butcher knives. The high incidence of knives may be a result of several factors: knives are easily obtained, easily concealed, and easily maintained. The infrequency of gun use may be an indication of the access, or lack thereof, that students have to guns in Canada.

Several American studies indicate that the use and possession of guns is on the increase (Wilcox and Clayton, 2001), and, as Siegel et al. succinctly put it, "as the number of guns in the hands of children increases so do the juvenile violence rates...guns can turn a schoolyard fight into a homicide" (2003, p. 37). However, the results of this study run contrary to the American findings. There is no evidence to suggest that the use of guns by secondary students in Southern Ontario is increasing in any significant way. Data on the number of students that are carrying guns to school were not made available for this study and consequently an opinion could not be expressed on the incidences of gun possession as it pertained to our sampled group.

Location of the Incidents: The low number of incidents occurring at extracurricular events is consistent with similar studies that consider the location of violent incidents. The Texas Independent School District Crime Report (Texas Education Agency, April 1995) reports that "less than $2 \%$ of the incidents occur at a sports event or extracurricular activity" (1995, p.11). This certainly would not be out of line with findings reflected in a purely Canadian context, where the links between the lack of participation in both in-school and out-ofschool extracurricular or leisure time activities is consistently linked with social maladjustment, school failure, and juvenile delinquency (Richardson, 2003, p.19; King, 1986, p.71).

Findings from this study indicate that incidents of violence typically occur in common areas of the school, such as halls and smoking areas. Supervised areas of the school, such as classrooms, extracurricular sporting events and cafeterias, are less likely to be the 
location of violent behavior.

These findings are comforting. Most of the teaching and learning process occurs in the classroom. With results indicating that these areas of the school are rarely the scene for disorder and chaos in the form of school violence, educators, parents, other staff and the community can be confident that the quality of education is not being jeopardized.

Gang-related Violence: There is no evidence from the results of this study to support literature claims that gang violence is on the increase in our schools(Cook and Laub, 1998; National School Safety Center, 1988).There was no reference to gang involvement in any of the student files.

Although a small number of incidents involved 2 to 3

perpetrators, these incidents were isolated and infrequent and the data did not indicate that these incidents had the trappings associated with gangs.

Specific Nature of the Offenses: Our results are comforting in light of similar studies, particularly American ones, that iterate an alarming number of victimized students (including deaths), as a result of violence experienced within the schooling environment (Siegel et al., 2003, p. 278; U.S. Department of Justice and Bureau of Justice Statistics, 2001, p. 6). For example, White (1994), in an investigation entitled "Caught in the Cross-fire: A Report on Gun Violence In Our Nation's Schools," tracks newspaper accounts over a five year period (1986-1990), noting that 71 persons (65 students and 6 school employees) were killed as a result of gun play at school. More recently, a comprehensive national government study, although noting a general decrease in the number of deaths occurring in American schools, nevertheless documents 2.5 million other criminal offences, including 186,000 serious violent crimes such as rape, sexual assault, aggravated assault, and robbery (U.S. Department of Education and Bureau of Justice Statistics, 2001).

As implied directly above, the results of our study indicate that 
no students have been killed as a direct result of school violence in the ten year span of this particular investigation. These findings are consistent with recent reports on the degree of serious violence that currently exists in Ontario schools, which show that documented fatalities within the educational domain are a rare occurrence indeed. However, based on our findings, we cannot agree with Rosemary Gartner, a sociologist at the University of Toronto, who claims that "school violence is all at the lower end of the crime scale" (Micromedia CBCA Record, 1996, p.1). More specifically, in most of the incidents studied in this report, the victims required medical attention, and in several cases the victims required extensive surgery and extended hospitalization. In the most severe attack on another student, the perpetrator was charged with attempted murder. In all other incidents where charges were laid, students were charged with assault or aggravated assault.

The victims and the perpetrators of the violence were most often students. The incidents of violence where teachers and staff were the victims were rare. Most often, teachers and staff were injured as a result of intervention. Although most incidents occurred between two male students, there were incidents between two females, females and males, and teachers and male students. There were no incidents that involved teachers and female students.

Teachers and Staff Involvement: The results of this study indicate that teachers and other staff are rarely the intended targets of student violence. In the two incidents where teachers were the intended victim, the teachers were verbally threatened by a student who possessed a weapon. In the remaining incidents involving teachers, teachers were assaulted by the students as a result of mediation. None of the assaults required that the teachers obtain medical attention.

This study's findings are consistent with similar studies that have explored the incidence of violence against teachers (British Columbia Teacher's Federation, 1999). The results also support the literature claims that classrooms and well-supervised areas of the 
school are not commonly the location of violence. In a Congressional Research Service Report, survey results indicate that " $2 \%$ [of the teachers] reported being physically attacked in the last 12 months." This is a very low percentage considering that the same report states that " $14-19 \%$ of 8 th, 10 th and 12 th graders reported being threatened with a weapon at school and $24-29 \%$ reported being threatened without a weapon at school" (White, 1994, p.8).

\section{Profiling how school boards are dealing with violent students}

The following variables were used to profile how schools and the school board are dealing with violent students:

- $\quad$ number of previous suspensions

- duration of expulsions,

- number of readmissions,

- conditions of readmission, and

- $\quad$ extent of police involvement.

Number of Previous Suspensions: The results of this study are consistent with the findings of similar studies indicating that students with a history of previous suspensions are at risk of expulsion for violent behavior (Skiba \& Peterson, 2000; Callahan and Rivara, 1992). Or as Howard Hampton, leader of the provincial NDP more dramatically puts it, generally, policies of zero tolerance, but more specifically, "the Ontario Safe Schools Act" should be more accurately referred to as the "Ontario Gang Recruitment Act" (Van Cooten, 2005, p. A21). Regardless, to what extent the schools are using this information to identify at risk students was not determined in this study.

The results of this study suggest that many schools are taking a one-chance approach when dealing with violent students. In almost half of the expulsions for violent behavior, the students expelled had one prior suspension for violent behavior. The second incident of violent behavior resulted in expulsion. Schools have, as indicated by the results of this study, adopted a one-chance policy respecting the tolerance of violence in Southern Ontario secondary schools. 
Duration of the Expulsions: Differences in the duration of expulsions exist and, as indicated by the results of this study, are related to a student's history of previous suspensions and academic achievement. In $75 \%$ of the cases, expelled students were not readmitted.

Percentage of the Students Readmitted: In the 14 cases where students were readmitted, readmission occurred within 2 to 3 years of expulsion, with $64 \%$ of the re-admissions occurring within less than one year of the expulsion date. As mentioned previously, in $75 \%$ of the incidents students were not readmitted.

The data indicate that the readmitted students were most frequently identified as average to good students and had 0 to 1 previous suspensions.

\section{Conditions of Readmission}

Analysis of the data indicates that there are several common conditions of readmission. In most incidents, students required reference letters. The sources of the reference letters were counselors, probation officers, psychologists, employers, and social workers. The second most common condition for readmission was that students obtained a psychological assessment. These assessments were primarily conducted by an "in-house" psychologist. No details of the assessment were available in the students' files. Community work, ongoing counseling, and professional assistance were less frequently cited as conditions of readmission. There were no data to suggest that students had been directed to specialty programs for expelled students and subsequently readmitted after successfully completing one of these programs.

Specialty programs for expelled students are praised for their success at effectively reintegrating violent students. They are justified by research indicating that the worst thing for society on the whole is to expel violent students. Many believe that these students are most in need of programs to teach them social norms.

This study found that of the 14 students readmitted, only one was subsequently re-expelled. It would appear that the efforts of 
counselors, psychologists, and probation officers are adequate for successful reintegration. The extent to which these professionals are using conflict resolution skills and hands-off policies was not known from the available data.

\section{Police Involvement}

The results of this study indicate that in slightly more than half of the incidents the police are being directly involved at the school level. The involvement of police in 30 of the incidents resulted in 27 student arrests. The available data indicate that the number of incidents involving the police has decreased by 55\% from September 1991 to August 1996. Some possible reasons for this sharp reduction may be the implementation of the Zero Tolerance Policy, better defined in-school policies for dealing with violent students, and factors attributed to the Young Offenders Act. This finding is in contradiction to more recent reports that claim the effects of Zero Tolerance Policies and the Young Offenders Act have been to increase the number of students charged with violent crimes (Ontario Human Rights Commission, 2005). Criminologist Anthony Doob states that after 1985, 16 and 17 year-olds were treated as youths "which artificially inflated the youth crime rate" (Micromedia CBCA, 1996, p. 1). The extent to which each of these factors (Zero Tolerance Policies and the Young Offenders Act) may have contributed to the decrease in the number of students charged is beyond the scope of this study.

\section{Discussion}

We realize that patterns can change over time, and that violence set within an educational milieu is certainly no exception (Vossekuil et al., 2000). With reference to this, after this study was completed, we asked officials of the board from which the study drew, whether or not, based on their personal experiences, there had been a significant change in trends over the past two or three years. In response to this query, most did not perceive much of a change other than that they felt that overall public concern had risen markedly and 
that threats of violence were more readily reported by senior school officials. However, the most current newspaper headlines would suggest otherwise. For example: Schools hand out tougher discipline: Suspension expulsion rates take huge jump (The Toronto Star, November 24, 2005).

There can be little doubt that the schooling experience plays a pivotal role in the development of latent human potential. Social maladjustment, often first manifested within the schooling experience itself, has the capacity to limit the development of this potential in a very profound way (Richardson, 2005). Restated, school failure and societal dysfunction, particularly as specifically related to criminality, have long been known to be correlated (McKinney, 1998; Polk \& Shafer, 1972). Hence, it would appear that the institution of schooling warrants much closer scrutiny because, delinquency-producing or not, it is the one mechanism that is the most pliable with respect to potential strategic manipulation. In short, as West implies (1984, p.204), when it comes to transcending variables which serve to negatively impact human potential, schooling deserves special attention because it is a public institution which lends itself very favourably to political change. Fundamentally, when everything is said and done, it just might be the best, and, in many instances, the only place to start.

Tragic as shootings are, they appear to be exceptional and highly random. We believe that this study may be useful to those who are concerned with day-to-day school violence.

In light of the findings of this study, particularly when juxtaposed with the plethora of literature consulted in its preparation, it seems that there are still several areas that merit future exploration. For studies which have as their focus etiology and strategic intervention with respect to students who exhibit violent behavior, incident reporting sheets should be completed for each individual student expelled, and these sheets should fully capture all demographic variables.

Future studies of this nature should be conducted and the results combined with existing studies in order that accurate and representative reports on the state of violence in Ontario Secondary Schools are communicated to educators, students, parents, and the community. 
The extent to which alternative programs for students expelled for violent behavior presently exist should be explored and the success of these programs measured in terms of successful student reintegration and successful completion of secondary school.

Further data on ethnic background should be obtained for the students involved in this study and, based on these data, a more accurate representation of frequency of expulsion for violent behavior according to ethnic background be determined.

Indicators such as a student's history of previous

suspensions and prior convictions are used to identify students at risk of expulsion for violent behavior (Dwyer, 1998). It is recommended that these indicators be used to direct at-risk students to programs designed to prevent violent behavior

To conclude, no one study provides a panacea. However, through the accumulation of small specific facts, contributions to knowledge can be made. As such, this study makes a modest yet meaningful contribution to the literature on school violence.

\section{References}

Agnew, R., \& Brezina, T. (1997). Relational problems with peers, gender and delinquency. Youth and Society, 29, 84-111.

Anon, (1999). Crackdown as Pupil Suspensions Soar. Sydney Morning Herald, 11 March.

Booth, J.W., Flick, T.M., Kirk, S.P.,Bradely, L.H., \& Keough, K.E. (1993). The violence at your door. Executive Educator, 1822.

British Columbia Teacher's Federation. (1999). Violence in British Columbia schools: Directions and dilemmas. Retrieved November 23, 2005 from http://www.bctf.bc.ca/ ResearchReports/99wlc06/report.html.

Brunner, M. (1993). Retarding America: The imprisonment of potential. Portland, Oregon: Halcyon House.

Callahan, C., \& Rivara, F. (1992). Urban high school youth and handguns. Journal of the American Medical Association, 267:3038-3042. 
Chan, D. W. (1996). Understanding and managing problem behaviors in schools: An integrative approach. Education Journal, Vol. 24, No. 2, Winter, 15-28.

Cook, P. J., \& Laub, J. H. (1998). The unprecedented epidemic in youth violence. In M. Tonry and M. H. Moore (eds.), Youth Violence. Chicago: University of Chicago Press.

Dwyer, K. (1998). Early warning, timely response: A guide to safe schools. Washington, DC: U.S. Department of Education, Government Printing Office.

Estevez, E., Musitu, G., \& Herrero, J. (2005). The influence of violent behavior and victimization at school on psychological distress: The role of parents and teachers. Adolescence, Sping.

Fink, C. M. (1990). Special education students at risk: A comparative study of delinquency. In Peter Leone (ed.), Understanding Troubled and Troubling Youth, Newbury Park, CA: Sage, 61-81.

Finn, J. D. (1988). School performance of adolescents in juvenile court. Urban Education, (23), July, (150-161).

Gibbons, D. C., \& Krohn, M. D. (1986). Delinquent behavior. Englewood Cliffs, NJ: Prentice-Hall Inc.

Hawkins, D. F., Laub, J. H., Lauritsen, J. L., \& Cothern, L. (2000). Race, ethnicity, and serious and violent juvenile offending. Juvenile Justice Bulletin, Washington, DC: Office of Juvenile Justice and Delinquency Prevention.

Heaviside, S., Rowand, C., Williams, C., \& Farris, E. (1998). Violence and discipline problems in U.S. public schools: 1996-1997. Washington, DC: Government Printing Office.

Holzman, H. R. (1979). Learning disabilities and juvenile delinquency: Biological and sociological theories. In C. R. Jeffery (ed.), Biology and Crime, Beverly Hills, CA: Sage, 77-86.

Horowitz, T., \& Tobaly, D. (2003). School vandalism: Individual and social context. Adolescence, Spring.

Hunter, B. E. (1993). Our self-destructive youth: A look at the problem and their causes. NASSP Bulletin. 52-58. 
Kalinowski, T. (2003). Does getting tough work? Toronto Star, 18 March.

Kalinowski, T. (2005). Schools hand out tougher discipline: Suspension expulsion rates take huge jump. Toronto Star, 24 November.

King, A.J.C. (1986). The adolescent experience. Report to the Ontario Secondary School Teacher's Federation. Toronto.

LeBlanc, M., Vallières, E., \& MacDuff, P. (1993). The prediction of males' adolescent and adult offending from school experience, Canadian Journal of Criminology, October , 459 -478 .

Leone, P.E., Mayer, M. J., Malmgren, K., \& Misel, S.M. (2000). School violence and disruption: Rhetoric, reality, and reasonable balance. Focus on Exceptional Children, 33, 1-20

Manning, M. L., \& Baruth, L. G. (1995). Students at risk. Needham Heights, MA: Allyn \& Bacon.

Mathews, F. (1995). Pilot project for students expelled for violent behavior. (Available from the Central Toronto Youth Services).

McEvoy, A., \& Welker, R. (2000). Antisocial behavior, academic failure, and school climate: A critical review. Journal of Emotional and Behavioral Disorders, 8, 130-140.

McKinney, J. D. (1998). Longitudinal research on the behavioural characteristics of children with learning disabilities. Journal of Learning Disabilities, 22, 141-150.

Micromedia CBCA Record. (1996). The truth about Ontario's rising youth crime rate. Canadian Press Newswire_(Accession \# 3636364) May 1996.

Murray, C. (1976). The link between learning disabilities and juvenile delinquency: A current theory and knowledge. Washington, DC: Government Printing Office.

National School Safety Center. (1988). Gangs in schools, breaking up is hard to do. Malibu, CA: Pepperdine University Press.

Ontario Human Rights Commission. (2005). A Review of the safe Schools Act.

http://www.ohrc.on.ca/en_text/consultations/safe- 
Profiling Expelled Students

schools_10.shtml

Retrieved November 25, 05.

Ontario Ministry of Education, (2001). Code of Conduct.

http://www.edu.gov.on.ca/eng/document/brochure/conduct/

conduct.html

Retrieved May 18, 04.

Paschall, M., Flewelling, R., \& Ennett, S. (1998). Racial

differences in violent behavior among young adults:

Moderating and confounding effects. Journal of Research in

Crime and Delinquency, 35: 148-165.

Polk, K. \& Schafer, W. (1972). Schools and delinquency. Toronto: Prentice-Hall.

Richardson, W.J. (2003). Class, schooling and juvenile delinquency: An eight year study. International Journal of Learning, (Vol. 10), 2909-2923.

Richardson, W.J., \& Richardson, C.A. (2003). Extracurricular activities and the at-risk/delinquent student: Implications for administrators. The CAP Journal, 12 (1), 18-20.

Richardson, W.J. (2005). Voices from the margins. Burnaby, BC: Aydy Press.

Roher, E. M. (1993). Violence in a school setting. Brock Education, 3(1), 1-4.

Sampson, R. J., Morenoff, J. D., \& Raudenbush, S. (2005). Social anatomy of racial and ethnic disparities in violence. American Journal of Public Health, Vol, 95, No. 2.

Shannon, L. (1982). Assessing the relationship of adult criminal careers to juvenile careers: A summary. Washington, DC: Government Printing Office.

Sheley, J.F., McGee, T., \& Wright, J. D. (1995). Weapon related victimization in selected inner-city high school samples. A final summary report presented to the National Institute of Justice (Report No. NCJ-151526). Washington, DC: National Institute of Justice.(ERIC Document Reproduction Service No. ED 381 598).

Short, J.,\& Strodtbeck, F. (1965). Group process and gang delinquency. Chicago: Aldine.

Siegel, L. J., Welsh, B. C., \& Senna, J. J. (2003). Juvenile 
K.Kirkwood and W. Richardson

delinquency: Theory, practice, and law. Toronto: Nelson Thompson Learning.

Skiba, R.J., \& Peterson, R.L. (2000). School discipline at a crossroads: From zero tolerance to early response. Exceptional Children, 66, 335-347.

Soriano, M., Soriano, F., \& Jimenez, E. (1994) School violence among culturally diverse populations: Sociocultural and institutional considerations. School Psychology Review, 23 (2), 216-235.

Texas Education Agency. (1995). Texas independent school district crime report_(Report No. GE5-601-613). Publications distribution division, Texas Education Agency. (ERIC Document Reproduction Service No. ED 382914.

U.S. Department of Education and Bureau of Justice Statistics, (2001). Indicators of school crime and safety. Washington, DC: Government Printing Office.

Van Cooten, M. (2005). Blacks are playing role in fighting gang violence. The Toronto Star, November 22.

Vossekuil, B., Reddy, M., Fein, R., Borum, R., \& Modzeleski, W. (2000). Safe school initiative: An interim report on the prevention of targeted violence in schools. Washington, DC: United States Secret Service, Government Printing Office.

Walker, H. \& Sylwester, R. (1991, September). Where is school along the path to prison? Education Leadership, 14-16.

West, W.G. (1984). Young offenders and the state. Toronto: Butterworths.

White, L. (1994). Violence in schools: An overview Washington, DC: Congressional Research Service. (ERIC Document Reproduction Service No. ED 369 169).

Wilcox, P., \& Clayton, R. (2001). A multilevel analysis of schoolbased weapon possession. Justice Quarterly, 18: 509-542.

Wolfgang, M. E, Figlio, R. M., \& Sellin, T. (1972). Delinquency in a birth cohort. Chicago: University of Chicago Press. 